Initial clinical trials have been carried out which demonstrate the effectiveness of this penicillin against a variety of penicillin-sensitive organisms at a dosage lower than that normally recommended for other oral preparations. Results of these trials are reported by Carter and Brumfitt (1962).

\section{Summary}

Phenoxybenzylpenicillin is a new acid-stable, orally active penicillin chemically related to penicillins $G$ and $\mathrm{V}$ and to phenethicillin.

In vitro its antibacterial spectrum and minimum inhibitory concentration against sensitive organisms has been shown to be similar to those of penicillin $\mathrm{V}$ and phenethicillin.

Studies in human volunteers at two dosage levels show that phenoxybenzylpenicillin gives higher and more prolonged therapeutic blood levels than penicillin $\mathrm{V}$ and phenethicillin. At the dose of $125 \mathrm{mg}$. phenoxybenzyl- penicillin gave a peak blood level greater than that from $250 \mathrm{mg}$. of penicillin $\mathrm{V}$.

Pharmacological tests have demonstrated a low oral toxicity. No allergic reactions were encountered, but phenoxybenzylpenicillin is likely to be similar to other penicillins in this respect.

The results suggest that phenoxybenzylpenicillin should have therapeutic advantages over existing oral penicillins and should be effective in lower dose levels at longer time intervals.

We acknowledge the contributions of our colleagues at Epsom, Bromborough, and Speke in this work.

\section{REFERENCES}

Carter, M. J., and Brumfitt, W. (1962). Brit. med. J., 1, 80. Garrod, L. P. (1960a). Bull. Hyg. (Lond.), 35, 384. - (1960b). Brit. med. J., 1, 527.

McCarthy, C. G., Wallmark, G., and Finland, M. (1961). Amer. J. med. Sci., 241, 143.

\title{
BACTERIOLOGICAL AND CLINICAL STUDIES WITH PHENOXYBENZYLPENICILLIN
}

\author{
BY \\ M. J. CARTER, L.R.C.P.\&S.Ed., L.R.F.P.S., B.D.S. AND $\quad$ W. BRUMFITT, M.D., M.R.C.P. \\ With Technical Assistance by I. WILLMOTT, A.I.M.L.T. \\ From the Department of Pathology, Edgware General Hospital, Middlesex, and the Wright-Fleming Institute \\ of Microbiology, St. Mary's Hospital, London
}

Since the discovery of 6-aminopenicillanic acid a number of new penicillins have been made available for laboratory and clinical assessment. Phenoxybenzylpenicillin (" penspek" ; D.C.(B.)L. 306) is the potassium salt of $6(\alpha$-phenoxyphenylacetamido) penicillanic acid with the structural formula:<smiles>CC1(C)SC2C(NC(=O)c3ccccc3Oc3ccccc3)C(=O)N2C1C(=O)O</smiles>

This paper describes absorption and excretion tests on human volunteers after oral administration of the compound. In addition microbiological assessment of phenoxybenzylpenicillin has been made, including a comparison with penicillins $V$ and $G$. The results of these investigations justified a clinical trial in which the therapeutic effect of phenoxybenzylpenicillin was assessed in patients suffering from infections due to a variety of penicillin-sensitive organisms.

\section{Absorption and Excretion}

Assay Procedure.-Penicillin serum levels were determined by the cup-plate biological assay method using Sarcina lutea (ATCC 9341) as the test organism. Standard penicillin solutions of the particular penicillin being investigated were included on each assay plate and the standard and test solutions were arranged so as to compensate for errors due to such factors as variation in thickness of the agar. For assay of serum the diluent for unknown samples and for the standard penicillin solutions was a $3 \%$ solution of bovine plasma albumin Fraction V (Armour Pharmaceutical Co.) in M/20 phosphate buffer $p H$ 7. For assay of urine the diluent for both unknown samples and standard penicillin solutions was $\mathrm{M} / 20$ phosphate buffer $\mathrm{pH} 7$.

Serum Levels.-Five volunteers received $125 \mathrm{mg}$. of phenoxybenzylpenicillin by mouth two hours after a light breakfast, and venous blood was removed at timed intervals. One week later the same subjects received $125 \mathrm{mg}$. of penicillin $\mathrm{V}$ two hours after a light breakfast

TABLE I.-Individual Serum Concentrations in Volunteers after a Single 125-mg. Dose of Phenoxybenzylpenicillin and Penicillin $V$

\begin{tabular}{|c|c|c|c|c|c|c|c|c|c|c|}
\hline \multirow{3}{*}{ Subject } & \multicolumn{10}{|c|}{ Serum Concentrations ( $\mu \mathrm{g} / \mathrm{ml}$.$) . Hours After Dose$} \\
\hline & \multicolumn{5}{|c|}{ Phenoxybenzylpenicillin } & \multicolumn{5}{|c|}{ Penicillin V } \\
\hline & $\frac{1}{2}$ & 1 & 2 & 4 & 6 & $\frac{1}{2}$ & 1 & 2 & 4 & 6 \\
\hline $\begin{array}{l}\mathbf{A} \\
\mathbf{B} \\
\mathbf{C} \\
\mathbf{D} \\
\mathbf{E}\end{array}$ & $\begin{array}{l}6 \cdot 0 \\
0 \\
1 \cdot 0 \\
0 \cdot 2 \\
1 \cdot 1\end{array}$ & $\begin{array}{l}3.0 \\
1.6 \\
2.0 \\
2.8 \\
2.2\end{array}$ & $\begin{array}{l}0.6 \\
1.7 \\
1.4 \\
1.0 \\
1.2\end{array}$ & $\begin{array}{l}0 \\
0.09 \\
0.1 \\
0.09 \\
0.1\end{array}$ & $\begin{array}{l}0 \\
0 \\
0 \\
0 \\
0\end{array}$ & $\begin{array}{l}1.4 \\
0 \\
0 \cdot 1 \\
0.1 \\
0.05\end{array}$ & $\begin{array}{l}1.5 \\
1.8 \\
0.5 \\
0.4 \\
0.8\end{array}$ & $\begin{array}{l}0.3 \\
0.6 \\
0.6 \\
0.7 \\
0.5\end{array}$ & $\begin{array}{l}0.04 \\
0.15 \\
0.04 \\
0.05 \\
0.04\end{array}$ & $\begin{array}{l}0 \\
0 \\
0 \\
0 \\
0\end{array}$ \\
\hline Average & $1 \cdot 6$ & $2 \cdot 3$ & $1 \cdot 2$ & 0.08 & 0 & 0.33 & $1 \cdot 0$ & 0.54 & 0.06 & 0 \\
\hline
\end{tabular}

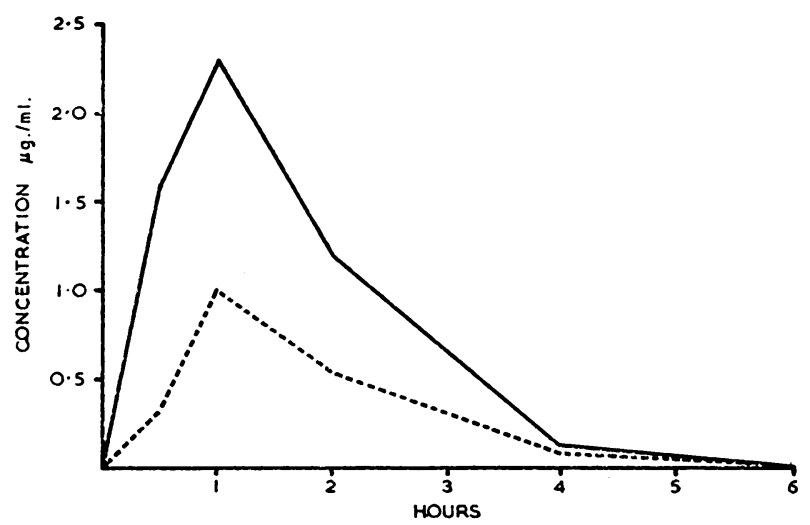

FIG. 1.-Comparison of serum levels of phenoxybenzylpenicitlin and penicillin $\mathrm{V}$ in five healthy subjects after an oral dose of $125 \mathrm{mg}$. ..... penicillin $\mathrm{V}$. phenoxybenzytpenicillin. 
and blood was removed at the same intervals as before. The individual results obtained with phenoxybenzylpenicillin and with penicillin $\mathrm{V}$ are shown in Table $\mathrm{I}$ and the average levels compared in Fig. 1. To investigate whether a dose of $250 \mathrm{mg}$. of phenoxybenzylpenicillin gave levels twice those found with $125 \mathrm{mg}$., estimations were made on sera from two volunteers who also took the larger dose. The results showed levels approximately twice those shown in Table I. Two further volunteers were given $125 \mathrm{mg}$. of phenoxybenzylpenicillin and venous blood was taken at timed intervals. They then continued to take $125 \mathrm{mg}$. of the compound every six hours for 48 hours and further estimations were made at the same intervals after the last dose. Thus serum levels could be compared after a single dose and after receiving continuous therapy (Table II).

TABLE II-Comparison Between Serum Concentrations of Volunteers After Receiving a Single Dose of $125 \mathrm{mg}$ Phenoxybenzylpenicillin and After $125 \mathrm{mg}$. Phenoxybenzylpenicillin Six-hourly for 48 Hours

\begin{tabular}{l|c|c|c|c|c|c}
\hline & \multirow{2}{*}{ Subject } & \multicolumn{3}{|c|}{ Serum Concentrations $(\mu \mathrm{g} . / \mathrm{ml}$.) Hours After Dose } \\
\cline { 2 - 7 } & & $\frac{1}{2}$ & 1 & 2 & 4 & 6 \\
\hline Single dose & $\mathbf{F}$ & 2.0 & 2.8 & 1.4 & 0 & 0 \\
& $\mathbf{G}$ & 0.2 & 2.2 & 2.8 & 0.3 & 0 \\
\cline { 2 - 7 } & Average & 1.1 & 2.5 & 2.1 & 0.15 & 0 \\
\hline $\begin{array}{c}\text { Continuous } \\
\text { therapy }\end{array}$ & F & 2.6 & 3.8 & 1.8 & 0.3 & 0 \\
& Average & 0.2 & 5.4 & 3.4 & 0.5 & 0 \\
\hline
\end{tabular}

Urine Levels. - The bladder was emptied immediately before taking the dose of phenoxybenzylpenicillin and subsequently each time blood samples were taken. The average urine penicillin levels of these specimens are shown in Fig. 2.

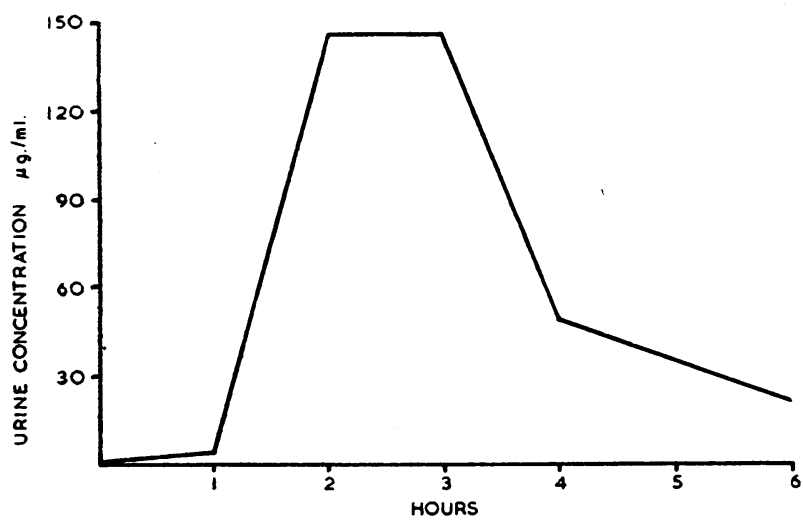

FIG. 2.-Average urine levels of phenoxybenzylpenicillin in five healthy subjects after an oral dose of $125 \mathrm{mg}$.

\section{Antimicrobial Activity of Phenoxybenzylpenicillin}

Minimum inhibitory concentrations (M.I.C.) of phenoxybenzylpenicillin, penicillin $G$, and penicillin $V$ required to inhibit the growth of bacteria for 24 hours at $37^{\circ} \mathrm{C}$. were determined by the serial dilution technique.

Dilutions of antibiotic in agar were poured into Petri dishes and the plates inoculated with a standard volume of an overnight broth culture. When necessary for bacterial growth $7.5 \%$ horse blood was also added to the nutrient agar. In a number of instances the M.I.C.s were also determined by the tube dilution method, using nutrient broth, and good agreement was found between the two methods. The results obtained with bacteria recently isolated in the laboratory from patients with clinically apparent infection are shown in Table III. Laboratory strains of bacteria whose M.I.C.s were known were used as controls with each batch of tests.

Bactericidal Activity.-An overnight culture of the Oxford staphylococcus was diluted in sterile nutrient broth which had been previously warmed to $37^{\circ} \mathrm{C}$. to give a viable count of about $10^{4}$ organisms. A similar dilution was also prepared, using nutrient broth containing human serum to give a final concentration of $40 \%$. Phenoxybenzylpenicillin was added in different concentrations and viable counts were carried out at intervals. It was found that $0.5 \mu \mathrm{g}$. of phenoxybenzylpenicillin per ml. sterilized both cultures within 12 hours and no inhibitory effect by the serum was detected. In further experiments the effect of inoculum size was investigated, but little or no effect on the bactericidal action of phenoxybenzylpenicillin was found within the limits $10^{8}$ to $10^{4}$ bacteria. Similar results were obtained in parallel experiments with penicillin $\mathrm{V}$.

Susceptibility to Penicillinase.-It can be seen in Table III that phenoxybenzylpenicillin has little activity against penicillinase-producing strains of Staph. aureus. Tests were carried out in which identical weights of penicillin $G$, methicillin, and phenoxybenzylpenicillin in solution were exposed to various dilutions of commercial Bacillus cereus penicillinase solution (Distillers Company (Biochemicals) Limited). After 30 minutes at $37^{\circ} \mathrm{C}$. the residual penicillin was assayed. From these crude experiments it was apparent that phenoxybenzylpenicillin had approximately the same susceptibility to penicillinase as penicillin $G$.

\section{Clinical Trial}

All patients included in the trial were seen by one of us personally before beginning antibiotic treatment. Most were suffering from acute infective conditions which could be assessed clinically. Material was

TABLE III.-Minimum Inhibitory Concentrations ( $\mu \mathrm{g} . / \mathrm{ml}$.)

\begin{tabular}{|c|c|c|c|c|c|c|c|c|c|}
\hline & & & \multirow{2}{*}{$\begin{array}{l}\text { No. } \\
\text { Tested }\end{array}$} & \multicolumn{2}{|c|}{ Penicillin G } & \multicolumn{2}{|c|}{ Penicillin V } & \multicolumn{2}{|c|}{ Phenoxybenzylpenicillin } \\
\hline & & & & Range & Average & Range & Average & Range & Average \\
\hline $\begin{array}{l}\text { Staphylococcus aureus: } \\
\text { Penicillinase-producing } \\
\text { Non-penicillinase-produ } \\
\text { Streptococcus: }\end{array}$ & ing & $\cdots$ & $\begin{array}{l}12 \\
11\end{array}$ & $0.12-0.03$ & $\begin{aligned}>50 \\
0.09\end{aligned}$ & $0.12-0.03$ & $\begin{array}{r}>50 \\
0.07\end{array}$ & $0.12-0.03$ & $>50$ \\
\hline 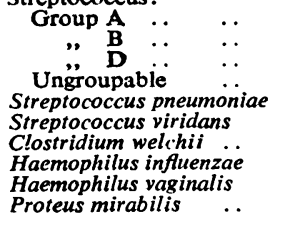 & $\begin{array}{l}\cdots \\
\cdots \\
\cdots \\
\cdots \\
\cdots \\
\cdots \\
\cdots \\
\cdots\end{array}$ & $\begin{array}{l}\cdots \\
\cdots \\
\cdots \\
\cdots \\
\cdots \\
\cdots \\
\cdots \\
\cdots\end{array}$ & $\begin{array}{l}9 \\
2 \\
6 \\
4 \\
4 \\
2 \\
2 \\
4 \\
1 \\
1\end{array}$ & $\begin{array}{c}0.03-0.006 \\
0.12-0 \cdot 12 \\
6 \cdot 0-6 \cdot 0 \\
0 \cdot 12-0.006 \\
0.006-0.006 \\
0.06-0.06 \\
2 \cdot 0-1 \cdot 0 \\
2 \cdot 0-1 \cdot 0 \\
4 \cdot 0 \\
20\end{array}$ & $\begin{array}{l}0.03 \\
0.12 \\
6.0 \\
0.06 \\
0.006 \\
0.06 \\
1.5 \\
1.7\end{array}$ & $\begin{array}{l}0 \cdot 06-0 \cdot 06 \\
0 \cdot 25-0 \cdot 25 \\
10 \cdot 0-8 \cdot 0 \\
0 \cdot 12-0 \cdot 006 \\
0 \cdot 06-0 \cdot 006 \\
0 \cdot 25-0 \cdot 125 \\
2 \cdot 0-1 \cdot 0 \\
10 \cdot 0-4 \cdot 0 \\
8 \cdot 0 \\
>160\end{array}$ & $\begin{array}{l}0.06 \\
0.25 \\
9.3 \\
0.06 \\
0.024 \\
0.18 \\
1.5 \\
7.5\end{array}$ & $\begin{array}{c}0.06-0.006 \\
0 \cdot 12-0 \cdot 12 \\
10-0-6 \cdot 0 \\
0.06-0.006 \\
0.012-0.006 \\
0.25-0.03 \\
2 \cdot 0-1 \cdot 0 \\
10 \cdot 0-4 \cdot 0 \\
8 \cdot 0 \\
116\end{array}$ & $\begin{array}{l}0.03 \\
0.12 \\
6.6 \\
0.03 \\
0.008 \\
0.14 \\
1.5 \\
6.5\end{array}$ \\
\hline
\end{tabular}


obtained for bacteriological examination, blood for total and differential white-cell counts, and the patients were then given a dose of $125 \mathrm{mg}$. of phenoxybenzylpenicillin which was repeated six-hourly.

Patients were seen again after 48 hours, by which time the pathogen responsible for the infection had been identified and its sensitivity tested by means of disks containing $2 \mu \mathrm{g}$. of phenoxybenzylpenicillin. When the organism was resistant more appropriate treatment was given and the patient excluded from the trial. When the infecting organism was sensitive to phenoxybenzylpenicillin progress was judged by clinical response, bacteriological findings, and the return of the white-cell count to normal. Further assessment was made at intervals of two days, and finally at 24 to 48 hours after stopping treatment.

Altogether 20 patients were treated, and these can be divided into three groups:

Group 1, Staphylococcal Infections.-Three patients with furuncle, three with pulp infections of the finger and accompanying lymphangitis, and one with an infected bunion.

Group 2, Streptococcal Infections.-Seven patients with acute febrile sore throat and one with an infected skin lesion, all due to group A streptococci.

Group 3, Miscellaneous.-This group was made up of single cases of gonorrhoea, bronchopneumonia (pneumococcal), sinusitis (pneumococcal), puerperal pyrexia (anaerobic streptococcus), and pyosalpinx (anaerobic streptococcus).

All patients, except the one suffering from pyosalpinx, responded promptly to treatment as judged by clinical improvement, the return of the white-cell count to a normal level, and bacteriological evidence of disappearance of the causative organism. The patient with pyosalpinx responded initially but then relapsed. Other antibiotics also failed and finally surgery was required.

During treatment the serum penicillin level was assayed on each patient at least once to confirm absorption, and satisfactory levels were found in every case. The actual levels obtained are given in Table IV. Patients were questioned about the appearance of symptoms which might indicate toxic or side-effects of the drug, but none were reported.

TABLE IV.-Random Serum Penicillin Levels (in $\mu \mathrm{g.} / \mathrm{ml}$.) in Patients Receiving an Oral Dose of $125 \mathrm{mg}$. Phenoxybenzylpenicillin at Six-hourly Intervals. The Figures Give the Accumulated Results from the 20 Patients Undergoing Treatment

\begin{tabular}{|c|c|c|c|c|c|c|c|c|}
\hline & \multicolumn{8}{|c|}{$\begin{array}{c}\text { Time in Hours After Receiving the Last Dose of Phenoxy- } \\
\text { benzylpenicillin }\end{array}$} \\
\hline & $\frac{1}{2}$ & 1 & $1 \frac{1}{2}$ & 2 & 3 & $3 \frac{1}{2}$ & 4 & 5 \\
\hline & $\begin{array}{l}0.6 \\
6.8\end{array}$ & $\begin{array}{l}6.0 \\
5.8\end{array}$ & $\begin{array}{l}4 \cdot 0 \\
3 \cdot 0 \\
0.5 \\
5 \cdot 0 \\
5 \cdot 0 \\
0 \cdot 5\end{array}$ & $\begin{array}{l}2 \cdot 3 \\
6 \cdot 0 \\
6 \cdot 2 \\
0 \cdot 4 \\
3 \cdot 2\end{array}$ & $\begin{array}{l}0.7 \\
1.2 \\
2.3 \\
1.1\end{array}$ & $\begin{array}{l}0.8 \\
0.5 \\
1.1 \\
0.7\end{array}$ & $\begin{array}{l}1.3 \\
0.1 \\
0.9 \\
1.5\end{array}$ & $\begin{array}{l}0.2 \\
0.08 \\
0.3\end{array}$ \\
\hline Average & $3 \cdot 7$ & 5.9 & $3 \cdot 0$ & $3 \cdot 6$ & $1 \cdot 3$ & 0.8 & 0.9 & $0 \cdot 2$ \\
\hline
\end{tabular}

\section{Discussion}

The studies of Garrod (1960a, 1960b) and McCarthy, Wallmark, and Finland (1961) have revealed marked differences in the activities of various penicillins. Assessment of antibacterial activity in vitro of phenoxybenzylpenicillin and penicillins $G$ and $V$ showed that, in terms of the M.I.C.s tested, phenoxybenzylpenicillin usually occupied an intermediate position between $G$ and V (Table III). Because of this the higher serum levels obtained with phenoxybenzylpenicillin compared with penicillin V (Fig. 1) reflect a true increase of antibacterial activity.

Adequate serum levels for the treatment of common infections such as those caused by group A haemolytic streptococci, penicillin-sensitive staphylococci, and pneumococci were obtained by the oral administration of $125 \mathrm{mg}$. of phenoxybenzylpenicillin six-hourly. Of the 20 patients suffering from such infections who were given this dosage 19 were cured. The remaining patient. who was suffering from pyosalpinx, responded initially but then relapsed, and, in spite of the administration of several other antibiotics, ultimately required surgery. Absorption of phenoxybenzylpenicillin was found to be reliable in all volunteers and patients who received the compound, and no untoward effects resulted from its administration.

It can be seen that both volunteers and patients receiving continuous therapy (Tables II and IV) have higher serum levels than volunteers who were given a single dose (Table I). Although no penicillin was detected in the serum six hours after a single dose of $125 \mathrm{mg}$. of phenoxybenzylpenicillin, the finding of higher levels in those subjects receiving continuous therapy suggests that the penicillin may be retained in the tissues for longer than six hours.

Phenoxybenzylpenicillin is inactivated by penicillinase and is of no value in the treatment of infections caused by penicillinase-producing staphylococci.

\section{Summary}

A new oral penicillin phenoxybenzylpenicillin has been investigated by microbiological testing in vitro, by absorption studies in volunteers, and by administration to 20 patients suffering from a variety of acute infections.

The antibacterial activity of phenoxybenzylpenicillin is intermediate between penicillins $G$ and $V$, and effective serum levels were found after oral administration of $125 \mathrm{mg}$. of the compound. This dosage given six-hourly proved adequate for the treatment of patients suffering from a variety of streptococcal, pneumococcal, and penicillin-sensitive staphylococcal infections. Absorption from the intestinal tract was found to be reliable, and satisfactory blood levels were present in all those who received the compound.

We are grateful to the members of the medical staff of Edgware General Hospital who referred patients to us for treatment. We also thank Dr. C. N. Brown and Dr. R. J. C. Cobbold, of the Distillers Company (Biochemicals) Limited, for the supply of " penspek."

\section{REFERENCES}

Garrod, L. P. (1960a). Bull. Hyg. (Lond.), 35, 384.

(1960b). Brit. med. J., 1, 527

McCarthy, C. G., Wallmark, G., and Finland, M. (1961). Amer. J. med. Sci., 241, 143 .

A one-day course in haematology entitled "The Diagnosis and Management of Anaemia" was held at the Royal Infirmary, Sheffield, on December 1. The course was organized by the Committee on Haematology of the Association of Clinical Pathologists, and some 72 consultants, senior registrars, and registrars in general medicine, surgery, and other specialties attended. 